\title{
信濃川左岸，時水背斜東翼の露頭に現れたタイプを異にする 活断層群とその解釈
}

\author{
鈴木 郁夫*太田陽子**吾 妻 崇*** \\ Interpretation of Various Types of Active Fault on Large Exposures within a Fold and \\ Thrust Belt at the Eastern Limb of the Tokimizu Anticline in Central Japan \\ Ikuo SUZUKI*, Yoko OTA** and Takashi AZUMA***
}

\begin{abstract}
The area at the middle to lower reaches of the Shinano River is a well-known major Neogene thrust and fold belt in Japan. Deformed fluvial terraces, such as anticlinal ridges, synclinal valleys, and fault scarps along the Shinano River, provide a good record of recent tectonic activity in this belt. A large exposure ( $c a .150 \mathrm{~m}$ long, and up to $10 \mathrm{~m}$ deep) was excavated by construction work on the eastern limb of the Tokimizu anticline, giving us an opportunity to observe various types of fault geometry.

Four faults - F1, F2, F3, and F4-cut terrace deposits of ca. 130-150 ka (Koshijippara terrace) and underlying early Pleistocene Uonuma Formation. The westernmost fault, F1 is represented as a remarkable flexure dipping westward, suggesting the presence of a low angle thrust underneath. We found a very low angle fault dipping eastward from an additional $2 \mathrm{~m}$ deep excavation. The vertical slip at F1, judged from the height difference with the top of the gravel bed (Bed V), is $12 \mathrm{~m}$. In contrast, faults F2 and F3 to the east of F1 follow the bedding plane of the steeply dipping Uonuma Formation, and are high angle reverse faults with the upthrown side to the east. The vertical slip is $3-4 \mathrm{~m}$ for F2 and $7.5 \mathrm{~m}$ for F3. Profiling across these faults shows that F1 is clearly expressed as a deformed terrace, but the topographical expression of F2 and F3 is not necessarily obvious. Similar faults to F2 are recognized in the study area from observations of the other three large exposures. We classify the faults in the study area into three types: Type 1 is a blind fault assumed at the base of the eastern limb of the Tokimizu anticline. This fault might be the most important contributor to the formation of the major tectonic relief in the study area, although we have no data to prove the nature of the fault plane itself from this study. F1 fault, demonstrated by Type 2, was found for the first time in this study, and is a low angle reverse fault truncating the structure of the Uonuma Formation with a vertical slip rate of 0.1 $\mathrm{m} / \mathrm{ka}$. The Type 3 fault is represented by F2, F3, and F4, and these are interpreted to be flexural slip faults along the bedding plane of the Uonuma Formation. Repeated faulting is confirmed from the progressive deformation of different beds not only for the F1 fault (Type 2) but also for the fold-related secondary faults, F2 and F3. No faulting has occurred since ca.7,500 years BP, however.
\end{abstract}

\footnotetext{
* 新潟大学名誉教授

** 横浜国立大学名誉教授

*** 独立行政法人産業技術総合研究所活断層研究センター

* Emeritus Professor of Niigata University

** Emeritus Professor of Yokohama National University

*** Active Fault Research Center, Geological Survey of Japan, AIST
} 
Key words : Tokimizu Anticline, low-angle reverse fault, flexural slip fault, fluvial terraces, growth of folding

キーワード：時水背斜, 低角逆断層, 層面すべり断層, 河成段丘, 褶曲構造の成長

\section{I. はじめに}

新発田一小出構造線（山下, 1970）以西の新潟 積成盆地の地形は，地殼変動に制約された数列の 丘陵・山地が北北東〜南南西方向に並走すること で知られる。この地域は Otuka (1941), 大塚 (1942)，池辺（1942）によって初めて指摘され た活褶曲地帯であり，この地帯を含む日本海東縁 および沿岸地域では 1964 年新潟地震 $(M 7.5)$, 1983 年日本海中部地震 $(M 7.7), 1993$ 年北海 道南西沖地震 $(M 7.8)$, 最近では 2004 年中越地 震（M 6.8），2007 年中越沖地震（M 6.8）など の大地震が短期間に発生している。

新潟県小千谷市の北部, 信濃川左岸の片貝西方 の地域（図 1）には, 活褶曲, 活断層が密に発達 する（Ota, 1969; Ota et al., 1973）。2004 年, 片 貝の西方（地点(1)）に，道路工事に伴う大露頭が 出現した。大露頭にはタイプを異にする断層がみ られたので，それぞれの断層の形状および変位量 を記載し，断層活動の累積性，およびタイプが異 なる断層の相互関連について考察した。さらに, 大露頭周辺の新しい露頭，筆者ら（太田・鈴木, 1979）が報告した露頭との関わりについても検 討を試みた。

\section{II. 調査地域の概観と調査方法}

この地域には，大局的には西に越路原面（約 $13 \sim 15$ 万年前), 東に小粟田原面（約 $5 \sim 6$ 万 年前)（早津・新井, 1982）が分布し，それらは 基盤の魚沼層の構造と調和する顕著な変位地形を 呈している（Ota, 1969; Ota et al., 1973）。すな わち, 越路原面はほぼ南北走向の活背斜（時水背 斜）丘陵に，小粟田原面は同方向の活向斜（小千 谷向斜）谷に当たる。両者の境界をなす急斜面に は背斜の成長に寄与した西傾斜の逆断層群が推定 され，その背後に位置する断層群を含めて片貝断
層群 (活断層研究会, 1980, 1991) と呼ばれている。 上述の南北走向の主構造に加えて, 越路原面上 にはこれらと並行する数本の比高の小さい断層崖 が分布する（図 1, 図 2)。これらの低断層崖は Ota（1969）によって示されていたが，変位量が 小さく, かつ露頭もそしかったため, 当時は西上 がりの断層と推定されていた。しかし, その後, 大規模な土砂採掘による露頭ができ（図 1 の地 点(4)), これらの小断層群が魚沼層の層面に沿っ て変位した東上がりの逆断層であり, 魚沼層を傾 斜不整合で覆う段丘礫層を変位させることが明ら かにされた（鈴木, 1977; 太田・鈴木, 1979)。こ の断層露頭は, 褶曲に付随する flexural slip fault（層面すべり断層）の典型例の一つとして 紹介されている（Yeats, 1986)。

今回, 小千谷市片貝西方 (地点(1)) の大露頭で, 地点(4)で見出したものと同様な層面すべり断層, および，それに加えて，より規模の大きな東上が りの低角逆断層を見出し，それらの精査を 2004 年 12 月以来数回にわたって実施した。2006 年 10 月には同露頭の東半で, 土砂採掘のため既存 の露頭底が約 $2 \mathrm{~m}$ 掘り下げられたので，その観 察も行った。

調査地点は, 上記の大露頭（地点(1)）を主とす る 3 地点である（図 1)。地点(1)は, 片貝から南 西の越路原にいたる道路の北側にあり, 越路原面 を変形させる時水背斜の東翼に位置している。こ こでは, 長さ約 $150 \mathrm{~m}$, 基底幅 $10 \sim 15 \mathrm{~m}$, 深 さ最大 $12 \mathrm{~m}$ の溝が掘られ (図 3), 南北両壁面 には魚沼層およびその上位の段丘堆積物・風成火 山灰とそれらの変形の様子が現れている。

本露頭および周辺において，筆者らは，（1）溝 (以下ではトレンチと呼ぶ) の基底の平面形状と 基底高度の測量（図 4)，（2） N2〜 N15，S2 $\mathrm{S} 13$ において地表まで垂直に設けた測線上での堆 積物の層相と高度の記録，（3）基準点間の層相と 


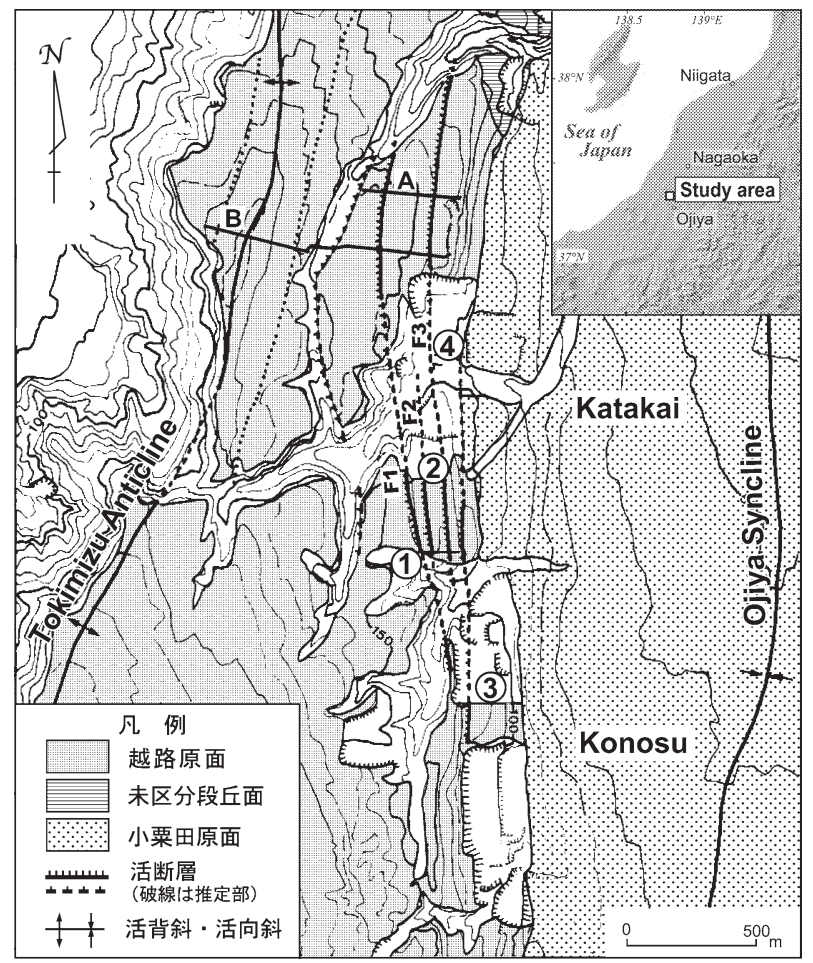

図 1 調査地域の地形と断層露頭および測線の位置.

地形分類と活断層は縮尺約 20,000 分の 1 および約 10,000 分の 1 空中写真判読と地形断面測量に 基づく，挿入図は調査地域の位置を示す.

Fig. 1 Landforms of study area, locations of fault outcrops and profile lines.

Terraces and faults are based on an aerial photograph interpretation at 1/20,000 and 1/10,000 scale. Inset indicates the location of the study area.

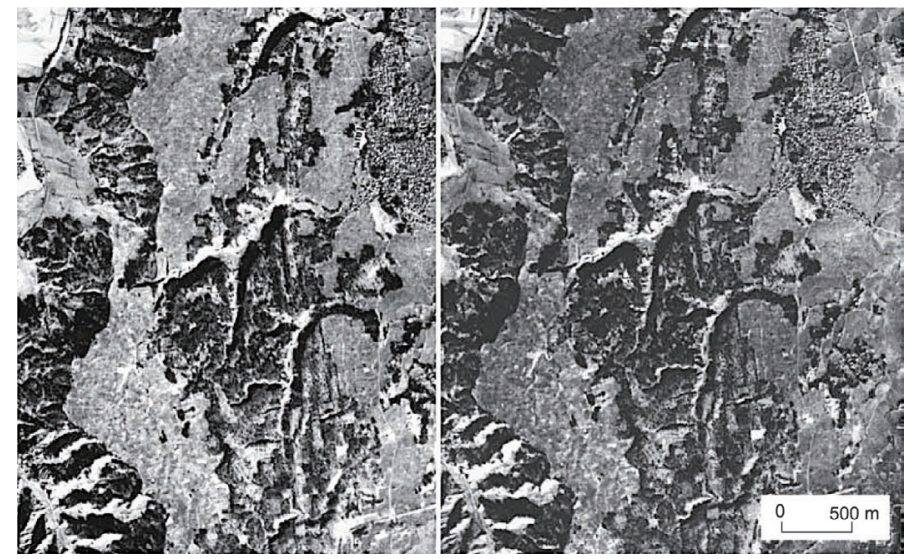

図 2 調査地域の地形を示す空中写真 (図 1 参照).

米軍撮影 40,000 分の 1 空中写真 (M640, No.71 おょび No.72) を使用.

Fig. 2 Stereoscopic view of the observed site (Photo by Army air forces, Photo numbers: M640, No. 71, and 72). Compare with Fig. 1. 
高度を遠望観察と写真からの図化で補いながら， 南北両壁面のスケッチ作成（図 $5 \mathrm{~A} \sim \mathrm{C}$ ), (4) 断層付近の詳細を示す写真の撮影（図 $6 \mathrm{~A} \sim \mathrm{E}$, 図 7), (5) 周辺の土砂採掘場, 地点(2), (3)での 露頭観察（図 8, 図 9),（6）地点(1)周辺の密な植 生を避けたトレンチ北方での 2 測線(図 1 の A, B) の地形断面測量（図 10), を行った。その際, ト

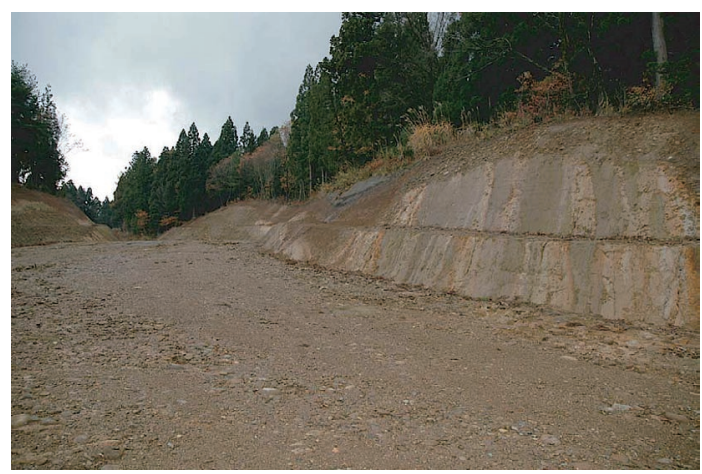

図 3 東方からみた地点(1)のトレンチ全景. 急斜する魚沼層とそれを覆う段丘堆積層.

Fig. 3 North wall of exposure at Loc. 1. Westward dipping deformation of terrace deposits overlying steeply bedded Uonuma Formation is clearly visible.
レンチで観察した断層と地形の変形との関係を確 認するために, 縮尺約 10,000 分の 1 カラー空中 写真, 約 20,000 分の 1 のモノクロ空中写真を用 いて地形分類図を作成し（図 1)，確認された断 層の位置を記入し，活断層の活動様式，変位量， 活動期および各活断層と褶曲との関係を考察した (図 11)。なお，考察に当たっては地点(4)の資料 （太田・鈴木, 1979）も加味した。

\section{III．地点(1)の露頭の記載}

\section{1）トレンチ壁に露出する地層}

越路原面を変形させる時水背斜東翼に位置する トレンチ壁には，東に急斜する魚沼層と，それを 不整合に覆う段丘構成層・風成火山灰層などが露 出する。段丘構成層は下部では砂礫層，上部では 細粒の氾濫原堆積物であり，その上位は風成火山 灰，および黒色の腐植土層である。これらを層相 の違いに基づいて，上位から I, II, III, IV, V 層に細分した（図 5A，C）。以下に，これらの層 相と厚さなどを記載する。

I 層：分解の進んだ厚さ $40 \sim 50 \mathrm{~cm}$ の黒色腐 植土層である。北壁の N13 付近では II 層を切る 浅い谷に土壤などが発達し, その厚さは約 $3 \mathrm{~m}$ である。このうちの下位の層から得られた試料の

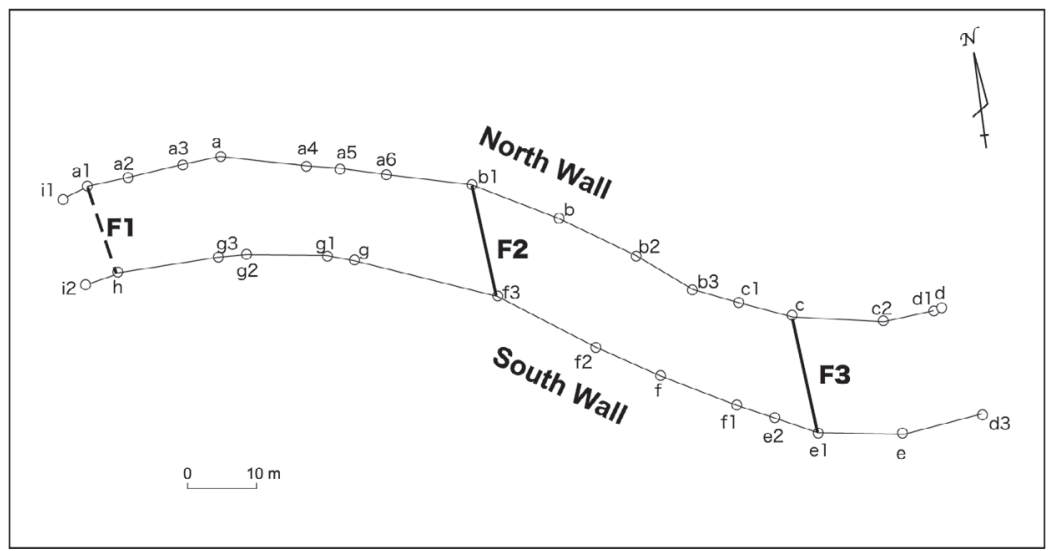

図 4 地点(1)のトレンチ底平面実測図.

アルファベットおよび数字と丸印は，測量に用いた基準点および計測点を示す.

Fig. 4 Plan view of excavation floor at Loc. 1.

Numbers at the edge of the floor show the locations of benchmarks, and indicate the locations of faults in the text. 

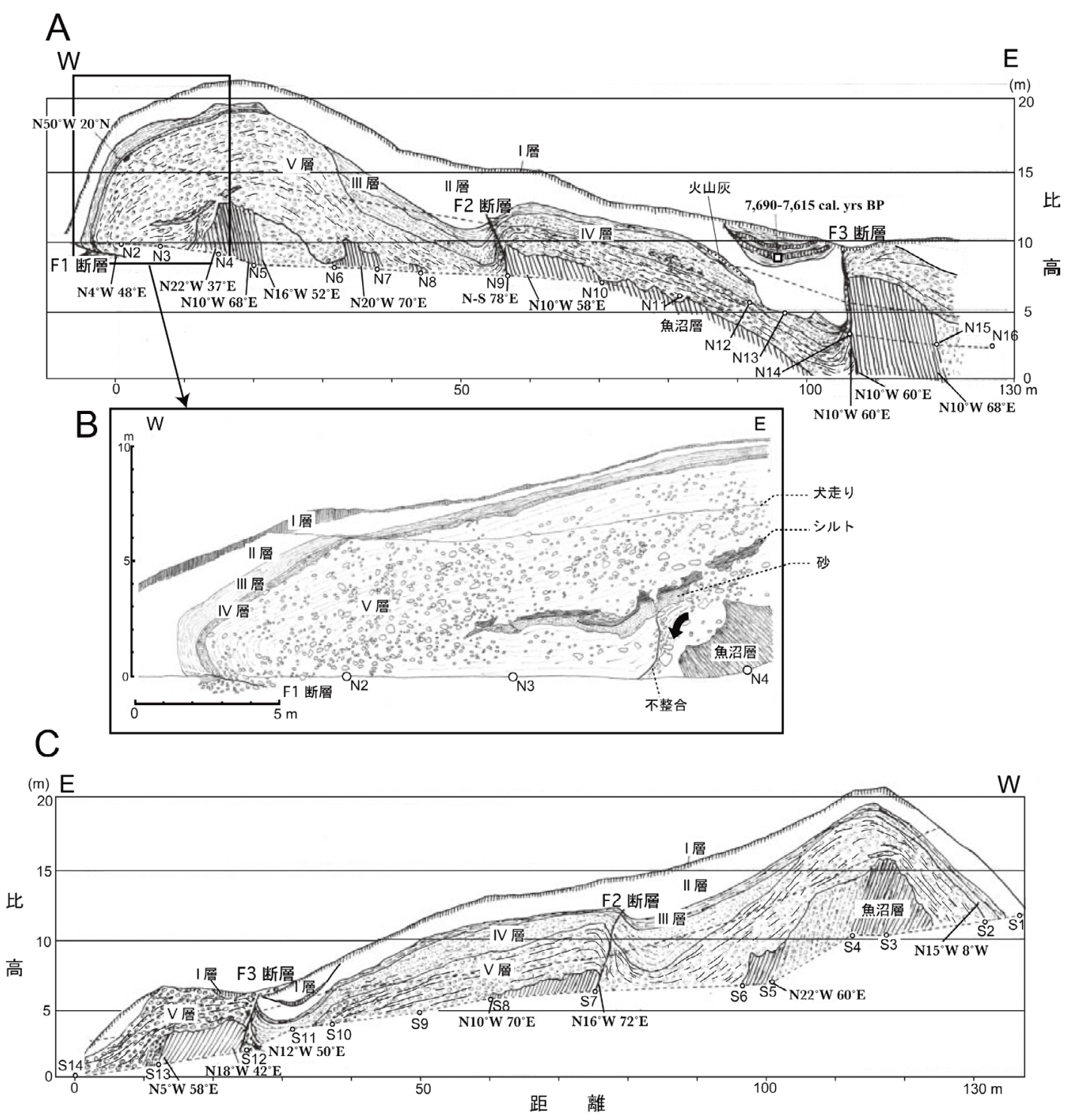

凡 例 : 画 土堙 $\square$ ローム

図 5 地点(1)の露頭スケッチ.

段丘堆積層と魚沼層の明らかな不整合，段丘堆積層とその被覆層を切る 3 断層（F1，F2，F3）.

$\mathrm{A}$ : 北壁全体. I 層 : 黒色腐植土層, II 層：風成火山灰層，III層：氾濫原堆積層（シルト）, IV 層：氾濫原堆 積層 (細砂), V 層：段丘堆積層.

$\mathrm{B}$ ：西方へ傾斜する段丘堆積層および被覆層を切る F1 断層付近の詳細図.

$\mathrm{C}$ ：南壁全体. A の数值は年代測定結果を示す。

Fig. 5 Sketch of excavation wall at Loc. 1

Clear unconformity between terrace gravel and Uonuma Formation, and three faults (F1, F2, and F3) cutting terrace deposits and coverbeds are shown.

A : North wall. Bed I: topsoil, Bed II: volcanic ash, Bed III: overbank deposits (silt), Bed IV: overbank deposits (fine sand), Bed V: terrace gravel.

B : Detailed sketch of F1 fault at the north wall showing a westward dipping deformation of terrace deposits and coverbeds.

$\mathrm{C}$ : South wall. Numeral in A shows date by ${ }^{14} \mathrm{C}$ dating. 
${ }^{14} \mathrm{C}$ 年代值（AMS 法）および較正プログラム CALIB 5.0.1 (Stuiver et al., 2005), ${ }^{14} \mathrm{C}$ 年代 暦年代較正曲線 IntCal04 (Reimer et al., 2004) を用いたその暦年較正值は，それぞれ $6,830 \pm$ 40 yrs.BP および 7,690〜 7,615 cal.yrs.BP (誤 差幅は 1 シグマ：IAAA-50939）である。

II 層: 厚さ約 $1.2 \sim 2.1 \mathrm{~m}$ の褐色風成火山灰層 で, 変形したIII層の汇濫原堆積物表面を覆う（II $\mathrm{a}$ 層)。この火山灰層中からは肉眼で識別可能な 鍵層は見出せなかった。

III 層 : 連続性のよい淡黄色のシルト層で, 厚さ は約 30〜 $40 \mathrm{~cm}$ である。トレンチ北壁の N2～N5, 南壁の S2～S3 では約 $50^{\circ}$ 西傾斜し，また F2， F3 の両断層（後述）による変位を受けてい る。

$\mathrm{IV}$ 層 : 厚さ $1.1 \sim 3 \mathrm{~m}$, 灰色の細砂・シルト層 で，F3 断層（後述）以西に連続良く分布するが, 北壁の N5 N6 および南壁の S4 S5 付近で はみられない。北壁の $\mathrm{N} 11 \sim \mathrm{N} 12$ 付近には 3 4 枚の白色軽石層が含まれ，それらの堆積構造に はやや乱れが観察された。また，本層の最下部に は, 層厚約 $5 \mathrm{~cm}$ の火山灰層が存在している。こ れらの軽石と火山灰について株式会社古環境研究 所に分析を依頼したところ，軽石については風化 が著しく分析が不可能であった。最下部の火山死 については, 角閃石, 斜方輝石, 磁鉄鉱が含まれ ており $(\mathrm{am}>>\mathrm{opx}>\mathrm{mt})$, 角閃石の屈折率 $\left(\mathrm{n}_{2}\right)$ は $1.677 \sim 1.681 て ゙, 一$ 部の角閃石は色調が薄い という結果を得た。この結果からは, 従来この地 域で報告されている指標火山灰との対比にはい たっていない。トレンチ西端の N2 付近では III 層 とほほ同様に約 $50^{\circ}$ 西傾斜し, F1 断層に近付く につれて次第に直立するようになる。

$\mathrm{V}$ 層（越路原面構成層）：信濃川起源の河成碟 層で，淘汰のやや悪い円礫ないし亜円礫からな り, 礫層下部には魚沼層起源の未固結の泥岩・砂 岩・シルト岩の砂が含まれることがある。最大礫 径は約 $50 \mathrm{~cm}$, マトリックスは小礫・粗砂で, 厚 さは約 $2 \sim 5 \mathrm{~m}$ である。 $\mathrm{N} 6$ 付近では, 魚沼層と の境界に深さ $1.5 \mathrm{~m}$ のポットホール状の凹みがみ られる。さらに, N3〜 N5 には厚さ $30 \sim 50 \mathrm{~cm}$
のシルト・粘土層がレンズ状に挟まり，それが N4 付近で西へ急傾斜し, 同じところで多くの扁 平礫が直立あるいは西へ傾いている。なお，北壁 の N5〜N6では魚沼層の砂部と V 層の境界がわ かりにくいこともあるが，南壁の S4～S5 では 魚沼層の礫部が急傾斜もしくは直立し，V層は緩 やかに傾斜している（図 7）ので，両者の区分は 容易である。

魚沼層：東に約 $60 \sim 70^{\circ}$ 傾斜する泥岩・シル 卜岩・礫層の互層からなり，V層とは起伏に富む 不整合で接している。これらの互層は, 前期更新 世（新潟県地質図改訂委員会, 2000）に堆積した 魚沼層の一部に相当する。魚沼層の礫層と $\mathrm{V}$ 層と を比べると，上述のように傾斜が異なるだけでな く, 魚沼層の礫のほうが砂径が小さく, 淘汰もよ く，マトリックスの固結度も高いといった特徴が ある。

\section{2）トレンチ壁でみられる断層の性状}

トレンチは，本地域の主構造とほぼ直交してい る（図 1)。このトレンチの南北両壁面には, 距 離約 $130 \mathrm{~m}$ の間に 3 本の断層（西から F1，F2, F3）が存在する（図 5A，C; 図 6A，B，C）。以 下では記載の便宜上, 断層面を露頭で直接観察で きた F3，F2 断層，ついで掘削調査を実施して断 層面を確認した F1 断層の順に記載する。なお, 北壁では F1 断層については詳細図を添えた（図 $5 \mathrm{~B})$ 。

F3 断層：本断層は，北壁の N14 および南壁の $\mathrm{S} 12$ にみられる走向 $\mathrm{N} 10^{\circ} \mathrm{W}$, 傾斜 $60^{\circ} \mathrm{E}$ の東上 がりの逆断層で, 魚沼層を不整合に覆う $\mathrm{V}$ 層を切 る。断層面は魚沼層の層面と一致しており, 層面 すべり断層である（図 5A, C)。北壁では F3 断 層の東で魚沼層および $\mathrm{V}$ 層が露出するが，図 $5 \mathrm{~A}$ のスケッチ作成時にはこれらの地層は断層の西に はみられなかったので, 正確な変位量は求められ なかった。しかし，2006 年秋の増し掘りによっ て, $\mathrm{V}$ 層が露出し, $\mathrm{V}$ 層上限の上下変位量が $7.5 \mathrm{~m}$ であることがわかった。断層をはさんで $\mathrm{V}$ 層および $\mathrm{V}$ 層は西に急に撓み下がり，断層に沿っ て幅 $20 〜 30 \mathrm{~cm}$ にわたって V層が引きずられ， 磁が断層に沿って直立している（図 5A）。断層の 


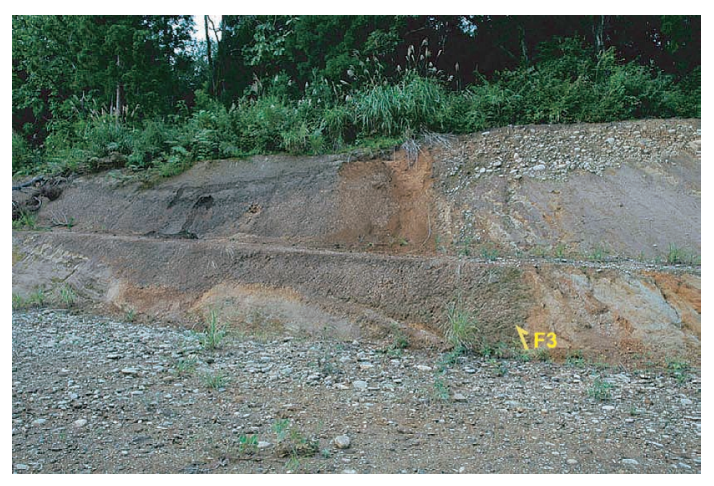

A

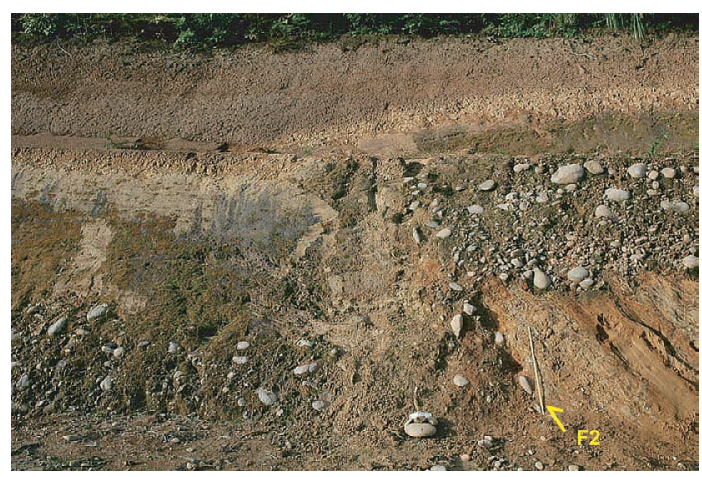

B

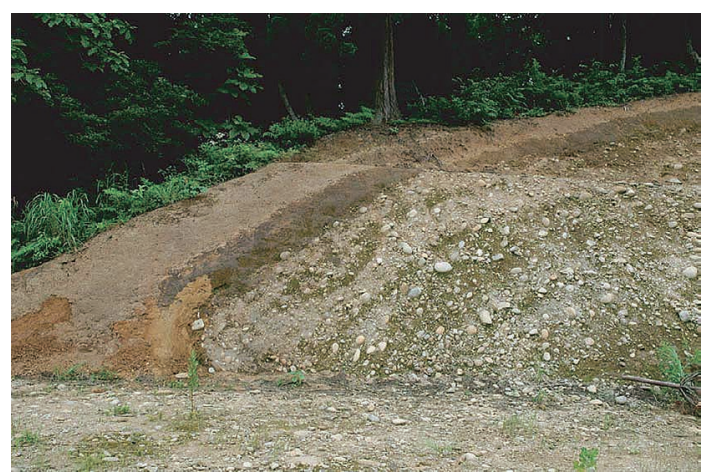

C

西には，IV 層の起伏を埋めて III層以上が厚さ $5 \mathrm{~m}$ 以上堆積し， II 層の上面は浅い谷で切られてい る。II 層の続きは N15 付近でみられ，断層両側 での II 層基部の高度差は $6 \mathrm{~m}$ 以上と見積もられ る。I 層は断層で切られていない。南壁では，V 層から III 層までに引きずり構造がみられ（図

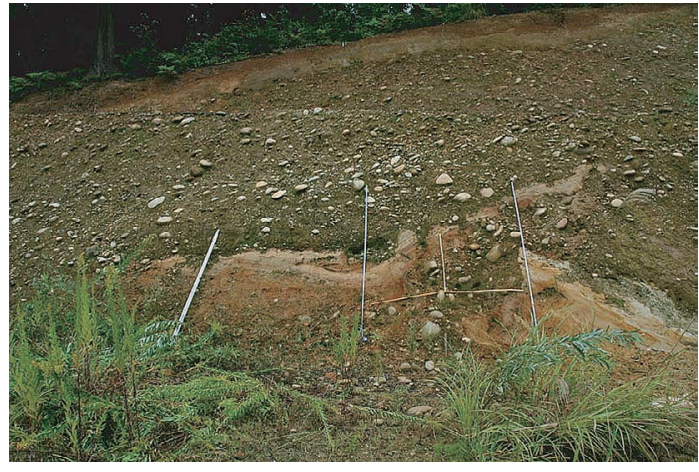

D

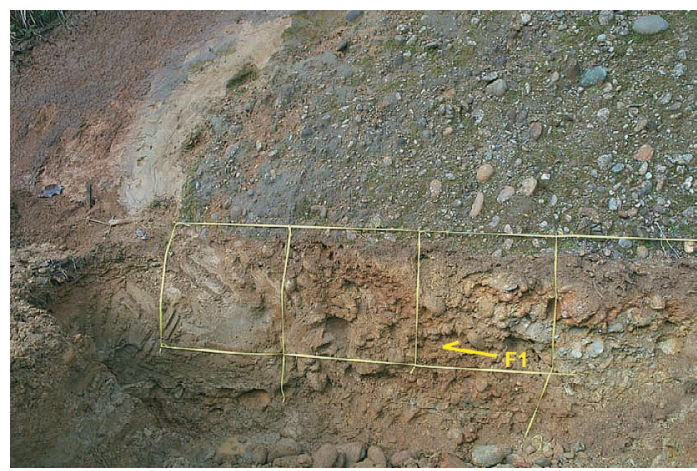

$\mathrm{E}$

図 6 地点(1)北壁での断層付近の写真.

A : F3 断層, B : F2 断層, C : F1 断層上盤における地 層の撓曲変形, $\mathrm{D} ： \mathrm{~F} 1$ 断層付近の $\mathrm{V}$ 層内の不整合, $\mathrm{E}$ : F1 断層の低角逆断層 (図 5B 参照).

Fig. 6 Photographs showing faults at the North wall, Loc. 1.

A : Close-up of F3 fault.

B : Close-up of F2 fault.

C : Hanging wall of F1 fault.

D : A minor unconformity within Bed V near F1 fault, suggesting activity during the deposition of Bed V.

$\mathrm{E}$ : Excavated low angle fault of F1. Bed V overlies Bed III.

5C)， III 層堆積以後に最新活動があったと考えら れる。 $\mathrm{V}$ 層上限の断層両側での高度差は約 $3 \mathrm{~m}$ であるが，ここでは上盤側のV層が侵食を受け， また下盤側では引きずりによる変形を受けている ため, $3 \mathrm{~m}$ はV 層堆積以降における F3 断層の上 下変位量の最小の值である。 
F2 断層：本断層は，F3 断層の西約 $50 \mathrm{~m}$ （北 壁の N9 および南壁の S7 付近）でみられる東上 がりの逆断層である。 $\mathrm{V}$ 層には断層上での撓み, 断層に沿う引きずりと，断層に沿って磁層が直立 しているのが認められる（図 5A，C）。断層の東 には，東に約 $60^{\circ}$ 傾く魚沼層が露出し，断層面は その構造と平行する層面すべり断層である。断層 両側での V 層上限高度の差は東上がり約 $3 \mathrm{~m}$ で ある。 $\mathrm{V}$ 層の層厚は断層の西では $3 \mathrm{~m}$ 程度, 東 では $1.5 \mathrm{~m}$ 程度で, IV 層堆積前にできていた起伏 を埋めている。F2 断層は, IV 層と III層の上面を それぞれ約 $1.9 \mathrm{~m}, 0.3 \mathrm{~m}$, II 層の下部をわずか に変位させているが，しかしながら II 層の大部分 およびI 層を変位させていない。南壁でも F2 断 層は層面すべり断層をなし，断層の下盤側で $\mathrm{N}$, $\mathrm{V}$ 層ともに下方へ湾曲した変形を示し， II 層もそ れと同様な変形を示している(図 5C)。

F1 断層：本断層に伴う変形はトレンチの西端 に位置し，北壁の $\mathrm{N} 4$ および南壁の S3 より西側 でのV層およびその上位の堆積物の顕著な西方へ の撓み（約 $50^{\circ} ）$ として表現され，N2 以西では $\mathrm{V}$ 層はオーバーターンしている（図 6C)。この変 形は, N3〜N7 にみられる東へ急斜 $\left(52^{\circ} \sim 70^{\circ}\right)$ する魚沼層の構造とは不調和であり，また東上が りの高角逆断層である F2, F3 断層とは変形の様 式が異なっている。すなわち, 上記の地層の変形 から，トレンチ面下に東に傾き下がる低角逆断層 の存在が推定される。しかし，露頭ではその断層 面が認められないので，北壁の N2 から N1にか けて，小型バックフォーを用いて底盤を約 $2 \mathrm{~m}$ 掘削した。そこでは，地表下 $1.2 \mathrm{~m}$ の深さで，約 $12^{\circ}$ へ傾斜する低角逆断層が $\mathrm{V}$ 層〜 III 層を切って いる様子が確認された（図 $6 \mathrm{E}$, 図 5B)。断層面 の上盤側では $\mathrm{V}$ 層の礫と III 層のシルトとが変形に より逆転している。断層を境とする $\mathrm{V}$ 層上限高度 の差は, 約 $12 \mathrm{~m}$ に達する。 F1 断層は, 3 断層中 で $\mathrm{V}$ 層の変位量が最大であり, かつ地表面も断層 と調和する変形を示している。

なお，既述のように， N3〜 N4 では V 層中の シルト・粘土層が西へ急傾斜し，その下位の多く の扁平礫が直立あるいは西に傾いている（図 5B,
図 6D)。しかし，その上部の礫層は西への傾斜 が下部層よりも緩やかであり，V層下部内に局部 的ではあるが不整合が認められる。したがって， シルト・粘土層堆積直後に西への傾きを生じさせ た活動があり， F1 断層が $\mathrm{V}$ 層堆積中にも活動し たことを示唆している。

南壁では $\mathrm{S} 4$ 付近に背斜状変形の頂部が位置し, それより西では魚沼層を不整合に覆う V 層が西 に急斜している。ここでは断層そのものは見出さ れない。南壁においても，北壁と同様に， IV 層お よびそれょり上位の堆積物および地表面は, V 層 上面と平行して撓んでいる。

\section{IV. そのほかの地点で観察された断層}

地点(1)の周辺では, 土砂採掘に伴ういくつかの 大規模な露頭があるが，現在稼働中のものが多 く，詳細なスケッチを作成するにいたっていな い。以下に，地点(2)小よ゙(3ににお批層とそれ に伴う地層の変形について簡単な説明をしてお <。

地点(2)：本地点は地点(1)の北側約 $400 \mathrm{~m}$ に位 置する越路原面を削った土砂採掘場の大露頭で, 北面する露頭の西端では礫層が西方へ撓んでいる のが観察される。その東側に，急斜する魚沼層の 層面と平行する断層面をもつ東上がりの高角な 2 本の逆断層があり，礫層を変位させる（図 8）。 地形的な連続性および地表変形の有無などの特徵 から，東側の断層は地点(1)の F3 断層に，西側の 断層は同じくF2 断層に当たると判断される。こ の露頭での F3 断層の変位量は, 礫層の上限を基 準とすると約 $10 \mathrm{~m}$ で，地表面にも比高数 $\mathrm{m}$ の 変形が認められる。

地点 (3)：本地点は, 地点 (1)から約 $500 \mathrm{~m}$ 南の 越路原面の東端に位置する土砂採掘場である。こ の地点では，北面する大露頭で東上がりの高角逆 断層が確認された。これを F4 断層と呼ぶ。F4 断層は断層面が急斜する魚沼層と平行しているの で，層面すべり断層であり（図 9), 地点(1)の F3 断層の南延長よりもやや東に位置している。した がって，この種の断層は，F2，F3 断層以外にも ほほ平行して分布しており，少なくとも 3 本存 


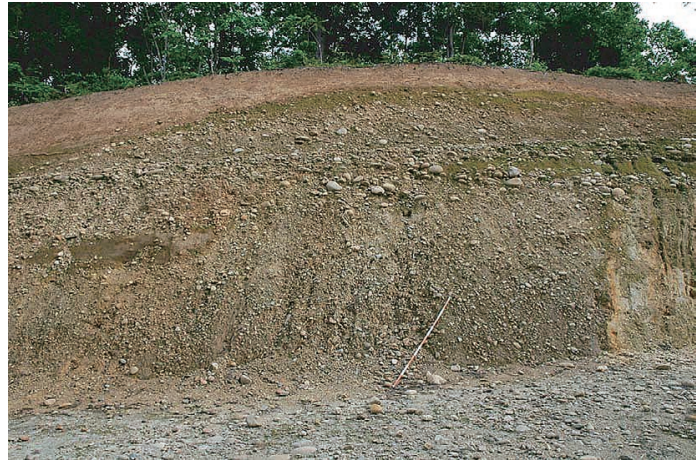

図 7 地点(1)南壁, $\mathrm{g} 1 \sim \mathrm{g} 2$ の間の写真. 急斜する魚沼層の碟部と, それを不整合に覆う段丘堆 積物（図 $5 \mathrm{C}$ 参照）。

Fig. 7 Photo of portion between g1 and g2 at the south wall, Loc. 1.

Unconformity between terrace gravel and steeply bedded Uonuma Formation at the South wall, Loc.1. (shown in Fig. 5C).

在することになる。

地点(4)：本地点（片貝中学校西）は，太田・鈴 木（1979）によって記載された大露頭であるが, 現在は土砂の採掘が進んで壁面が大きく後退した うえ，植生に覆われているので，当時の様子を観 察することができない。この露頭では 4 本の東 上がりの高角逆断層が認定され，いずれも急斜す る魚沼層の層面と平行する断層面をもつ層面す心゙ り断層であった。それぞれの断層の変位量は数 $\mathrm{m}$ 以下であるが, その一部は地表面の変形とし ても現れていた。これらの断層は, 地点(1)の F2, F3 断層と同様なものであり，位置からみて F3 断層，F4 断層およびそれより東に位置する断層 に当たると判断される（図 1）。

\section{V. 露頭でみられた断層と地形との関係}

地点(1)で観察された F1 断層では，堆積物の変 形と調和して段丘面の西への撓み下がりが明瞭で ある（図 5A，B）。しかし，F2 断層については 地表面には変形がみられず, F3 断層については, わずかに東上がりの傾向があるが（図 5A），段丘 面が樹木に覆われている地点(1)付近では，地形面 の変形はよくわからない。そこで，この地点から

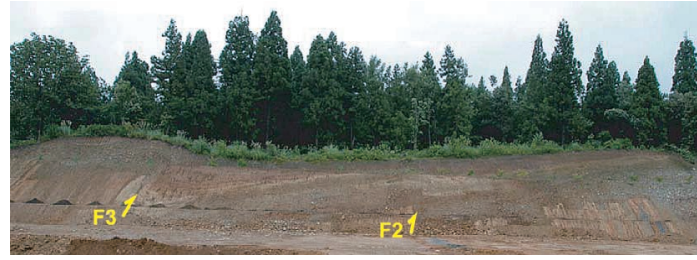

図 8 地点(2)の断層露頭写真.

北から南を望む. 左端が地点(1)の F3 断層, 中央に同 F2 断層に対応する活断層.

Fig. 8 Photo of Loc. 2 looking southward. Two faults, probably corresponding to F3 and F2 at Loc. 1 are visible.

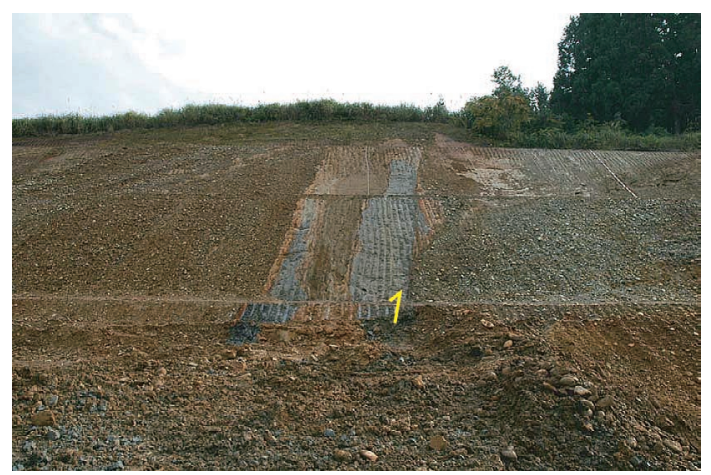

図 9 地点(3)の断層露頭写真.

北から南を望む. 矢印で示した F4 中央部の断層は地 点(1) F3 断層よりも東に位置する層面すべりで, 東 上がりの逆断層.

Fig. 9 Photo of Loc. 3 looking southward. Arrow shows F4 fault, further east of Fault 3 at Loc. 1, flexural slip fault and reverse fault.

北に約 $1.25 \sim 1.5 \mathrm{~km}$ 離れているが，見通しの よい場所に, 測線 A, B を設定して地形断面測量 を行った（図 10）。

測線 $\mathrm{A}$ では F1 断層の北延長と思われる西への 撓みが越路原面上に認められる。そこから約 $150 \mathrm{~m}$ 東に，東上がりを示す区間がある。これ は地点(1)の 3 本の断層の位置および地点(2)の連 続性などから判断すると, F3 断層に当たる可能 性が大きいが，F2 断層による段丘面の変形は認 められない。測線 A より約 $500 \mathrm{~m}$ 南に位置する 測線 B では, 主構造である背斜構造が越路原面 の変形として明瞭に現れ，F1 断層はその東翼付 


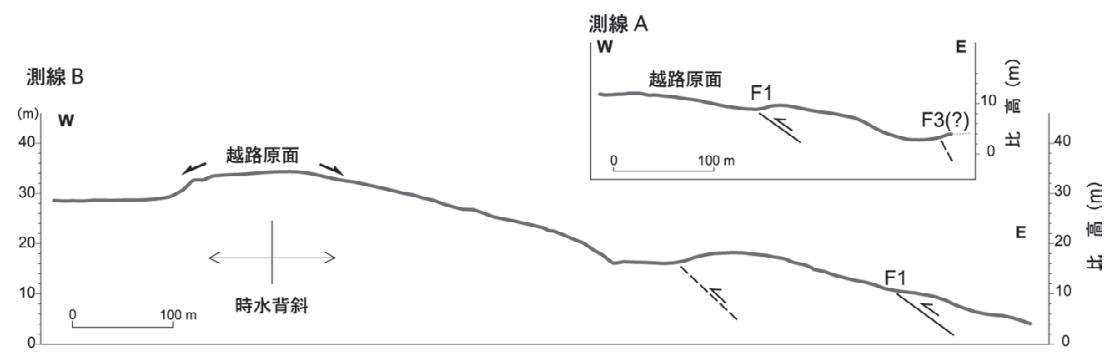

図 10 測線 A, B での実測地形断面図（測線位置は図 1参照).

Fig. 10 Measured topographical profiles with the locations of observed faults (shown in Fig. 1).

近の減傾斜として表現されている。この F1 断層 の西では段丘面が逆傾斜することから東上がりの 断層の存在が推定され，それに沿って南北方向の 浅い谷がある。

露頭観察と地形断面形状を考慮すると, F1 断 層による段丘面の上下変位量は，地点(1)で約 $12 \mathrm{~m}$, 測線 $\mathrm{A}, \mathrm{B}$ 付近では約 $2 \mathrm{~m}$ と, 北に向かっ て減少する。このような北方への変位量の減少 は，本地域の主な背斜軸上でみられた傾向（Ota， 1969）と同様である。

以上のように, 背斜東翼の逆断層群のうちで, 低角逆断層である F1 断層は，地形にみごとに現 れていて連続性もよく，その長さは少なくとも2 $\mathrm{km}$ である。それに対して，層面すべりの高角逆 断層であるF2，F3 断層などは，変位量が小さ く，段丘面のわずかな逆傾斜として現れるか，ま たは地形には全く表現されていない。越路原面に おける変形および各地点の資料を総合すると, こ の種の断層は背斜東翼に少なくとも5 本あり, 図 1 の範囲におけるそれらの断層群の長さは $3 \mathrm{~km}$ 程度である。

\section{VI. 活断層の累積性と活動時期に関する検討}

F1 断層 : F1 断層の両側における V 層上限高度 の差は，北壁で約 $12 \mathrm{~m}$ ，南壁で $8 \mathrm{~m}$ 以上で，今 回見出された断層のうちで最大の変位量を示して おり，段丘面の変形として地形に明瞭に現れてい る。これらの変位量と越路原面の推定形成年代 （約 $13 \sim 15$ 万年前; 早津・新井, 1982） から求め られる平均上下変位速度は $0.1 \mathrm{~m} /$ 千年で，断層
の活動度としては $\mathrm{C}$ 級〜 $\mathrm{B}$ 級最下位の值である が，断層の傾斜角 $\left(20^{\circ}\right)$ を考慮した断層面上で の平均実変位速度は約 $0.3 \mathrm{~m} /$ 千年となる。既述 のように，V層には西に急斜する砂碟層とそれを 覆って西へ緩やかに傾斜する礫層との間に不整合 があり（図 5B)，V 層堆積中に少なくとも 1 回 の活動があったことは確かであるので，最大 $12 \mathrm{~m}$ という上下変位量が 1 回の断層活動によっ て形成されたとは考えられず，複数回の活動を示 唆していると思われる。

F2 断層： $\mathrm{V}$ 層上限高度の差（北壁で $3 \mathrm{~m}$, 南 壁で $4 \mathrm{~m}$ ), IV 層の上限高度の差（北壁で $1.5 \mathrm{~m}$, 南壁で $2 \mathrm{~m}$ ), III 層， II 層下部を切る F2 断層の 存在などから考えて，「IV層堆積以降」，および $「$ III 層堆積以降」の少なくとも 2 回の断層活動が あったことが推定される。IV層の層厚が，北壁で は断層の西側で $3 \mathrm{~m}$, 東側で $2 \mathrm{~m}$ 以下，南壁で は西側で最大 $4 \mathrm{~m}$, 東側で $1 \sim 2 \mathrm{~m}$ と異なるこ とから，IV層の堆積直前には既にこの断層は活動 していたことがわかる。そのときの断層崖は $\mathrm{N}$ 層 により埋積されるが，その後而層堆積以降に再活 動した。II 層にはその基部の一部を除いて変位の 証拠はないため，この断層の最新活動時期が II 層 堆積後となるかどうかは現状では判断をつけるこ とがむずかしく，あったとしてもその活動時の上 下変位量は II 層下部の変位量から求めると約 $0.3 \mathrm{~m}$ である。

F3 断層 : $\mathrm{F}$ 断層の両側では， $\mathrm{V}$ 層上限高度に 北壁で約 $7.5 \mathrm{~m}$, 南壁で $4.3 \mathrm{~m}$ の差が認められ る。また，II 層は， III， IV 層を刻む谷地形を埋め 


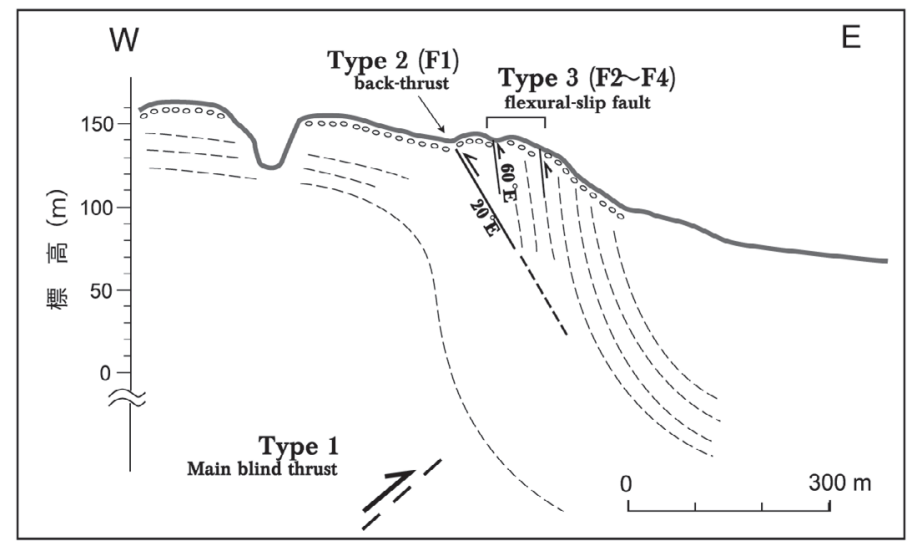

図 11 本地域の活褶曲と 3 種の活断層との関係を示す解釈図.

Fig. 11 Schematic diagram showing three types of fault with related to folding structure.

て堆積した後に, F3 断層で切られている。II層 は断層の西で厚さ $5 \mathrm{~m}$ であるが，断層の東には 認められない。II層を刻む谷地形を埋める I 層の 腐植層などのうち，とくに腐植の濃い下部層から の ${ }^{14} \mathrm{C}$ 年代は 7,690 7,615 cal.yrs.BP (IAAA50539）であった。したがって，F3 断層は少なく とも「II 層堆積期以前」と「II 層堆積期以降, I 層堆積期以前」の 2 回の活動歴があったと推定 される。また, IV 層の層厚が断層の西側で厚いこ とから, IV 層が堆積する前から既に東上がりの崖 地形が存在していたことが推定され，「V 層堆積 後, IV 層堆積以前」にもう 1 回の活動の可能性 が大きい。この断層の最新活動期は，この断層の 上端が I 層の黒色土を切っていないことから判断 して, II 層堆積期以降, I 層堆積期以前（約 7,000 年前以前）となる。F3 断層は, V 層の変 位量からみて F2 断層よりも変位量が大きく複数 回の活動が確実で，これが段丘面の変形に現れて いる所以である。

\section{VII. 活断層と活褶曲との関係}

本地域には，今までに知られていたように，主 に東西方向の圧縮によって段丘面が南北方向の活 褶曲による変形を受け，時水背斜丘陵（越路原頂 部）と小千谷向斜谷 (小粟田原中央部の浅い谷), および両者の間に位置する片貝断層群による変位
地形が形成されている。さらに，時水背斜東翼に は東上がりのセンスをもつ多数の南北方向の小断 層群が分布する (太田・鈴木, 1979; 活断層研究会, 1980; 堤ほか, 2001; 渡辺ほか, 2001)。これらの 一部は, 1970 年代末に観察された大露頭（地点 (4)ににおいて，初めて層面すべり断層として認識 され（鈴木, 1977; 太田・鈴木, 1979), 裮曲に伴 う副次的断層として扱われた。今回の調査で見出 された F2〜 F4 断層，および太田・鈴木 (1979) により地点(4)で記された 4 本の断層（本稿の F3, F4 断層を含む) はいずれも裮曲の成長に伴う層 面すべり断層であり，片貝周辺では少なくとも 5 本の存在が確認される。ただし，すべての断層が 段丘の変形として現れているわけではない。ま た, 背斜東翼に位置する小断層の一つであるが, $\mathrm{F} 1$ 断層は他の断層と比べて変位量が大きく, 地 形への表現が明瞭であるとともに, 段丘堆積物と 段丘面の西への撓みを伴う低角逆断層であり，魚 沼層の構造を切っているといった特徴がある。

片貝周辺で観察される変位地形の特徵を, 地形 断面資料と合わせて検討した（図 11）。まず，背 斜と向斜およびそれらの境界に位置する断層は, 本地域の大局的な地形を形成する構造であり，地 下に伏在する低角逆断層とそれに伴う褶曲構造で あると解釈される。これらの地形を形成した地下 の伏在断層を第 1 タイプの断層と呼ぶ。すなわ 
ち, 時水背斜の東翼の構造は, 第 1 タイプの断 層と関連した断層伝播褶曲（fault-propagation fold）と解釈される。越路原面の東縁を限る撓曲 崖の比高は約 $50 \mathrm{~m}$ 以上であり，この比高と越路 原面の形成年代（約 $13 \sim 15$ 万年前, 早津・新井, 1982）から算出される，断層の平均上下変位速 度は $0.4 \mathrm{~m} /$ 千年以上であり，断層面の傾斜を考 慮した場合の断層面上の平均変位速度はそれ以上 である。

本地域において，第 1 タイプの断層による変 形についで明瞭な変位地形を形成しているのが, F1 断層である。この断層は地表付近では断層面 が低角で，上盤側で地表に撓みを伴い，断層崖の 基部には断層と平行する谷地形が発達する。これ は時水背斜東翼の活断層群のうちでもっとも顕著 な変位地形をもち, 魚沼層の構造を切っているこ とから, F2〜 F4 断層のような層面すべり断層と は区別し，ここではこれを第 2 タイプの断層と 呼ぶ。第 2 タイプの断層は, 第 1 タイプの断層 の共役断層として断層の上盤に形成されたバック スラストの一種と推定される。

魚沼層の層面に沿って発生している F2～F4 断層などの層面すべり断層を，ここでは第 3 夕 イプの断層と呼ぶ。これらは, 裮曲構造の成長に 伴って生じる曲げ応力を解消するために発生した 層面すべりである。これら第 3 タイプの断層に よる変位量は小さく, 地形としては認識されない こともある。

第 2 , 第 3 タイプの断層は, 平均変位速度や断 層の傾斜角などに違いがみられるものの, 基本的 には第 1 タイプの断層の活動に付随して形成さ れる逆向き低断層崖として地形表現が明瞭である 点で類似している。また，第 3 タイプの断層は 褶曲付随型であり, 第 2 タイプの断層も第 1 夕 イプの断層の上盤に形成される共役断層であると 解釈されるため, いずれも起震断層となるもので はなく，これらが独自に活動したとは考えられな い。しかし，これらの活動にも累積性があること がわかり, 第 1 タイプの断層活動時期の一部を 表すものと思われる。なぜ, 本地域で 2 種類の 副次的な断層が生じたかについては, さらに検討
を要する課題である。

\section{VIII. まとめ}

小千谷市片貝から越路原への道路工事現場（地 点(1)）において 3 本の断層（F1，F2，F3 断層） の記録を取り, 各断層の活動時期や変位量をまと めるとともに, 周辺の露頭や地形で観察される情 報と合わせて, この地域に存在する断層を 3 つ の異なるタイプの断層に分類し，それぞれの特徴 を検討した。

（1） F1 断層は東上がりの低角 $20^{\circ}$ 以下の逆断 層であり, 基盤の魚沼層の構造を切っている。越 路原面（約 $13 \sim 15$ 万年前）構成層堆積以降の 上下変位量は約 $12 \mathrm{~m}$ で, 平均変位速度は上下成 分で約 $0.08 \sim 0.1 \mathrm{~m} /$ 千年, 断層面の傾斜方向上 で約 $0.3 \mathrm{~m} /$ 千年である。段丘構成層である $\mathrm{V}$ 層 堆積中を含めて断層活動は複数回あると考えられ るが，時期の特定はできなかった。

（2）F2，F3 断層は，東上がりの高角逆断層で あり，基盤の魚沼層の層面すべりから発生してい る。 $\mathrm{V}$ 層における上下変位量は $\mathrm{F} 2$ 断層で 3 〜 $4 \mathrm{~m}, \mathrm{~F} 3$ 断層で $7.5 \mathrm{~m}$ であり，いずれの断層に おいても上位層で変位量が小さくなることから活 動の累積性が認められる。平均変位速度は 0.02 〜 $0.03 \mathrm{~m} /$ 千年であり, 変位地形として認識でき ないことがある。活動時期は F2 断層では, 少な くとも「I 層堆積以降」と「III層堆積以降」であ り, F3 断層では「 $\mathrm{V}$ 層堆積以降 IV 層堆積以前」 $\lceil$ II 層堆積以前」「II 層堆積以降, I 層堆積（約 7,000 年前）以前」である。

（3）片貝地域に認められる断層は，(1)褶曲構 造（断層伝播褶曲）の形成に関与している西傾斜 の逆断層（第 1 タイプ），(2)第 1 タイプの断層に 対して共役関係にあるバックスラスト（第 2 夕 イプ), (3)褶曲の成長に伴って生じる層面すべり 断層（第 3 タイプ）に区分される。これらのう ち起震断層となりうるのは第 1 タイプの断層で あろう。しかし, 露頭で確認された第 2 , 第 3 夕 イプの断層は第 1 タイプの断層の活動による褶 曲構造の成長に伴って動き，かつ累積的な変位を 示している。 


\section{謝 辞}

地点(1)の F1 断層の浅部掘削に関する許可の取得およ び掘削工事は小千谷市の黑崎銀次郎氏の協力による。 無償で掘削工事を引き受けて下さった同氏に深く感謝 する。断面測量には阪神コンサルタンツの佐藤 賢氏 の協力を得た。長岡市立科学博物館の加藤正明氏から は，2006 年秋の増し掘りに関する情報を頂いた。以上 の方々に㧍礼を申し上げる。

\section{文献}

早津賢二・新井房夫 (1982): 信濃川流域（新潟県小千 谷市付近）に㧍ける河成段丘群の形成年代と段丘面 の変位速度. 地理学評論, 55, 130-138.

池辺展生 (1942): 越後油田褶曲構造の現世まで行われ ていることに就いて (講演要旨). 石油技術協会誌, 10, 108-109.

活断層研究会編（1980）：日本の活断層一分布図と資 料一. 東京大学出版会.

活断層研究会編 (1991): 新編 日本の活断層一分布図 と資料一. 東京大学出版会.

新潟県地質図改訂委員会 $(2000)$ : 新潟県地質図同説明 書 (2000 年版). 新潟県.

Ota, Y. (1969): Crustal movements in the late Quaternary considered from the deformed terrace plains in Northeastern Japan. Japanese Journal of Geology and Geography Japan, 40, 41-61.

太田陽子・鈴木郁夫（1979）: 信濃川下流地域における 活褶曲の資料. 地理学評論， 52，592-601.

Ota, Y., Machida, T., Ikeda, H., Shirai, T. and Suzuki, T. (1973): Active folding of the fluvial terraces along the Shinano River, central Japan. The Crust and upper Mantle of the Japanese Area, Part II, Ge- ology and Geochemistry, Geological Survey of Japan, 121-129.

Otuka, Y. (1941): Active rock folding in Japan. Proceedings of Imperial Academy of Japan, 17, 518522.

大塚弥之助（1942）: 活動している褶曲構造. 地震， 14, $46-63$.

Reimer, P.J., Baillie, M.G.L., Bard, E., Bayliss, A., Beck, J.W., Bertrand, C.J.H., Blackwell, P.G., Buck, C.E., Burr, G.S., Cutler, K.B., Damon, P.E., Edwards, R.L., Fairbanks, R.G., Friedrich, M., Guilderson, T.P., Hogg, A.G., Hughen, K.A., Kromer, B., McCormac, F.G., Manning, S.W., Ramsey, C.B., Reimer, R.W., Remmele, S., Southon, J.R., Stuiver, M., Talamo, S., Taylor, F.W., van der Plicht, J. and Weyhenmeyer, C.E. (2004): IntCal04 terrestrial radiocarbon age calibration, 26-0 ka BP. Radiocarbon, 46, 10291058.

Stuiver, M., Reimer, P.J. and Reimer, R. (2005) : CALIB5.0.1 radiocarbon calibration program.

鈴木郁夫 (1977): 土地分類基本調查 5 万分の 1 「小千谷」 の地形分類（図）および同説明書. 新潟県，11-27.

堤 浩之一東郷正美 - 渡辺満久 - 金 幸隆・佐藤尚登 (2001): $1: 25,000$ 都市圈活断層図「長岡」. 国土地理 院技術資料 D - 1-No.388.

山下昇（1970）柏崎一銚子線の提唱. 島弧と海洋, 179-191.

Yeats, R.S. (1986): Active faults related to folding. Studies of Geophysics and Active Tectonics, National Academy Press, 63-79.

渡辺満久 - 堤 浩之 - 鈴木康弘 - 金 幸隆 - 佐藤尚登 (2001): $1: 25,000$ 都市圈活断層図「小千谷」. 国土地 理院技術資料 D · 1-No.388.

$(2007$ 年 9 月 11 日受付, 2008 年 3 月 17 日受理 $)$ 